\title{
TRANSIENT STABILITY ANALYSIS FOR DETERMINING CRITICAL CLEARING TIME IN ULUMBU GEOTHERMAL POWER PLANT
}

\author{
Aventus Wagur, Abraham Lomi, Irrine Budi Sulistiawati
}

\begin{abstract}
The presence of 3 comparable phases in the Ulumbu geothermal power plant affects the existing system, so it is necessary to conduct stability analysis to be able to find out the Critical Clearing Time (CCT) of the Circuit Breaker system that can maintain its synchronous condition. The results of the transient system analysis to determine the Critical Clearing Time were carried out when the 3 phases of the Ulumbu geothermal power plant were 0.4 seconds and showed that the level of voltage, frequency, and rotor angle would be faster..
\end{abstract}

Index Terms - Transient, Critical clearing time, Rotor stability angle

\section{INTRODUCTION}

$\mathrm{T}$ ransient stability analysis of electric power systems is a very important problem for the continuity of safe and sustainable electric power system operations. This transient stability is the ability of an electric power system to maintain synchronization after experiencing a sudden major disturbance for about one "Swing" assuming that the automatic voltage regulator (AVR) and governor have not worked [1].

In general, the stability of the rotor angle is taken as an index of the transient stability of electric power, which is a function of operating conditions and disturbances related to the ability of the electric power system to remain intact after experiencing interference [2]. The transient stability analysis of the electric power system involves calculating the critical break time (Critical Clearing Time) to eliminate disturbances. Critical Clearing This time is defined as the maximum allowable time at which interference is eliminated so that the existing system remains stable or does not lose synchronization. The electric power system will remain stable if the interference is eliminated in the specified critical termination time.

In this thesis will be discussed about transient stability analysis, which is an analysis to determine the critical termination time at the Ulumbu geothermal

Aventus Wagur, college student in the electrical engineering program, Institut Teknologi Nasional Malang (Phone : 082330809348, email: wagurven@yahoo.co.id)

Abraham Lomi, lecturer in the electrical engineering program, Institut Teknologi Nasional Malang (Phone : 0818387674, email: abraham@itn.ac.id)

Irrine Budi Sulistiawati, lecturer in the electrical engineering program Institut Teknologi Nasional Malang (Phone : 08123386004 , email: irrine elektro@lecturer.itn.ac.id)

power plant when there is a balanced three phase disturbance so that it can overcome system instability. The analysis was carried out using ETAP Power Station Software to determine the amount of change and recovery time from the rotor angle when there was a balanced 3 phase disturbance on the Ulumbu PLTP.

\section{METHODOLOGY}

\section{A. Single Line Diagram}

Figure 3.1 shows the Manggarai Region Single Line Diagram display that has been drawn on ETAP software. Ulumbu geothermal power plant is a plant that will be analyzed for its transient stability when there is a balanced 3 phase disturbance on one bus from the Ulumbu PLTP to the Manggarai regional network system.

\section{B. Data Parameters of the Manggarai Electrical System}

Data parameters that have been obtained during the survey at PT. PLN (Persero) Rayon Manggarai includes:

- Generator data

- Transformer data

- Load Data

- Line Data.

After that, it will be inputted into the Single Line Diagram that has been drawn on ETAP software.

The tables in the following are the generating data tables and load data for each feeder on the Manggarai electrical system.

\section{Generating Data}

Table 3.1 Generating Data

\begin{tabular}{|l|l|}
\hline Pembangkit & Generation (Mw) \\
\hline Pltd Waso & 0.88 \\
\hline Caterpilar & 0.7 \\
\hline Komatsu & 0.72 \\
\hline Kubota & 0.56 \\
\hline Man \#1 & 0.56 \\
\hline Man \#2 & 0.56 \\
\hline Man \#3 & 0.56 \\
\hline Mtu & 3.5 \\
\hline Mercedes Benz/M. Sewa & 0.12 \\
\hline Pltmh Wae Garit & 10 \\
\hline PLTMH Wae Garit & *Example Data \\
\hline Pltp Ulumbu & \\
\hline PLTP Ulumbu &
\end{tabular}




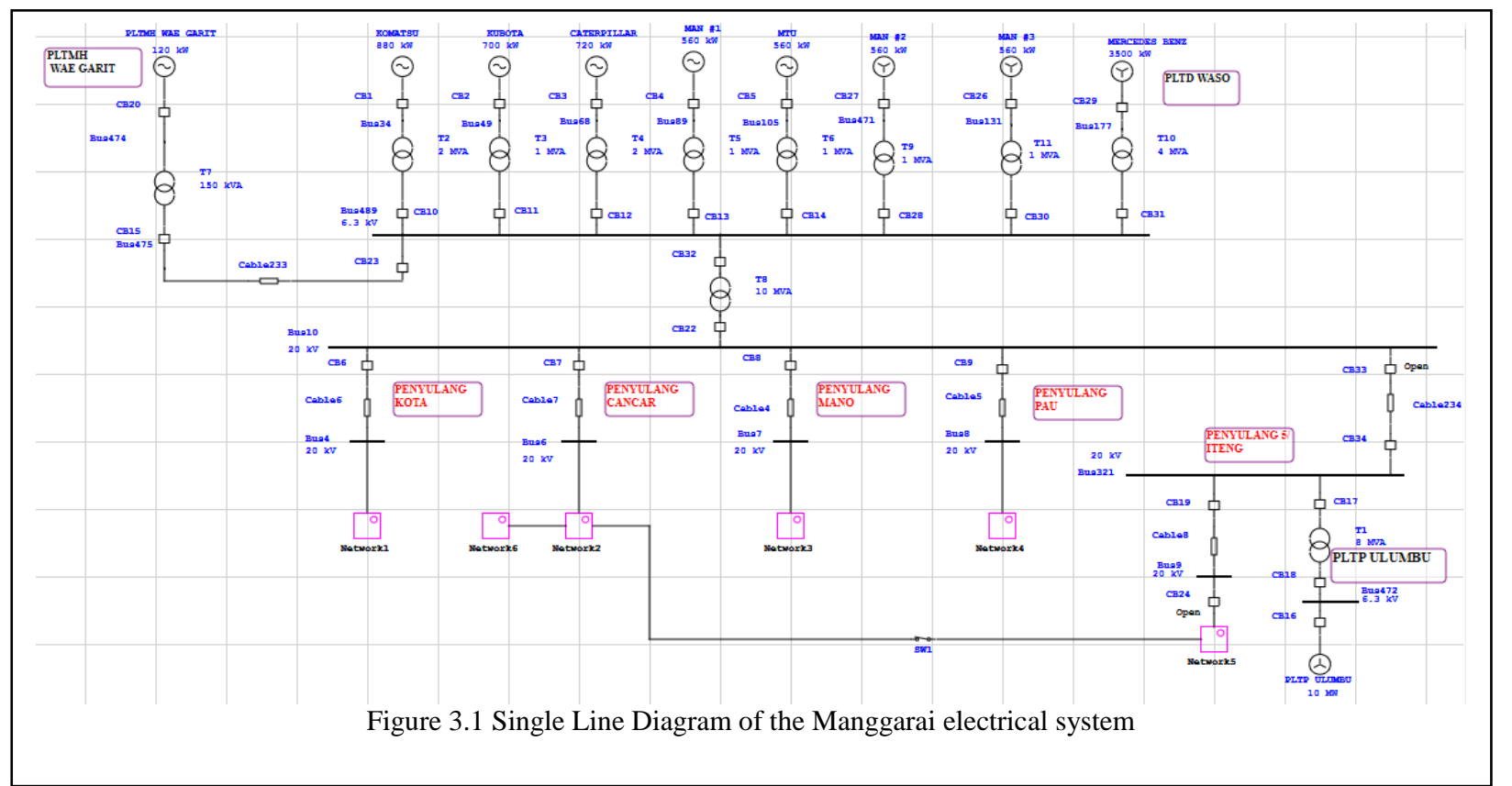

\section{Load Data}

Table 3.2 Load Data

\begin{tabular}{|l|l|}
\hline Feeder & Load (Kva) \\
\hline Kota & 3590 \\
\hline Cancar & 2300 \\
\hline Mano & 1075 \\
\hline Pau & - \\
\hline Iteng & 1800 \\
\hline
\end{tabular}

\section{Simulation Process}

Based on the data obtained, a simulation process will be carried out on ETAP Power Station software. The Transient Stability Analysis Mode is used to determine the stability of the system transient which includes rotor angle stability in order to determine the change in the rotor angle of the Ulumbu geothermal power plant when there is a 3 phase balance that requires transient stability analysis to determine the Critical Clearing Time of the Circuit Breaker and changes in the rotor angle of the generator in the Manggarai Region electricity system when the Ulumbu PLTP is injected into the system.

\section{Flow Chart}

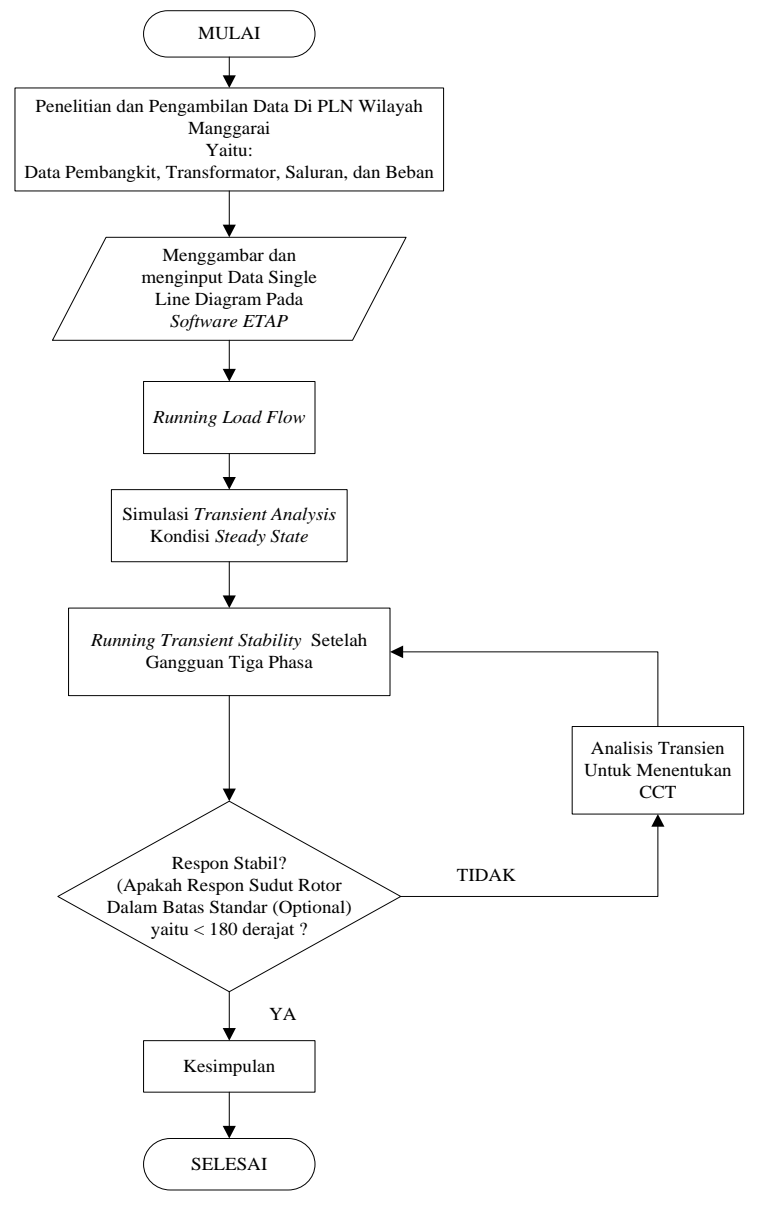

Figure 3.2 Work Flow Chart 


\section{RESULT AND ANALYSIS}

In the Manggarai electrical system simulation will be carried out on four conditions, namely:

1. Normal condition

2. Condition of Manggarai Generation System when there are 3 phase disturbances

3. Condition of 3 Phase Disorders in the Ulumbu PLTP with a specified Critical Clearing Time

3 phase disturbances occur on Bus 9 which is the Bus connected from the Ulumbu PLTP to the Iteng Feeder (Feeder 5).

\section{A. Transient Stability of the Manggrai Literature} System

a. Rotor Stability, Frequency and Angle Manggarai Normal Conditions

Normal conditions are conditions in which the system has not experienced interference or the system is still in normal condition. Under normal circumstances this will be seen as normal conditions of voltage, frequency, and rotor angle on bus 6 and bus 10. Bus 6 and bus 10 are buses where there are 3 phase disturbances and the bus is injected by Ulumbu PLTP.

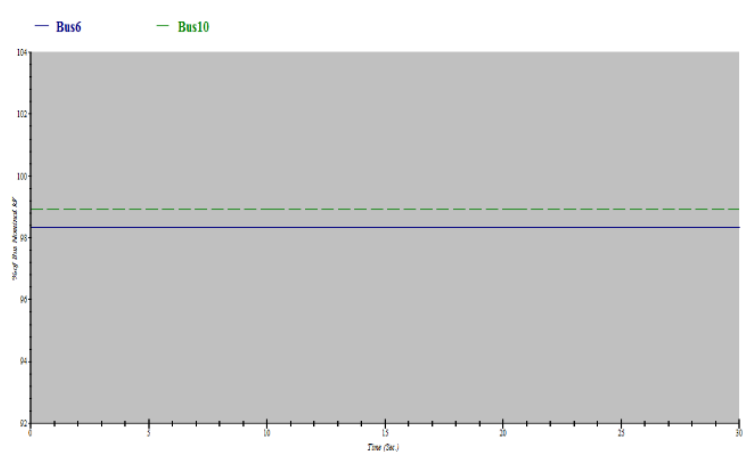

Figure 4.1 Response of Voltage Stability Value Normal Conditions

In Figure 4.2 below is a picture of the stability response of the normal conditions of bus 6 and bus 10 in the electrical system of the Manggarai region.

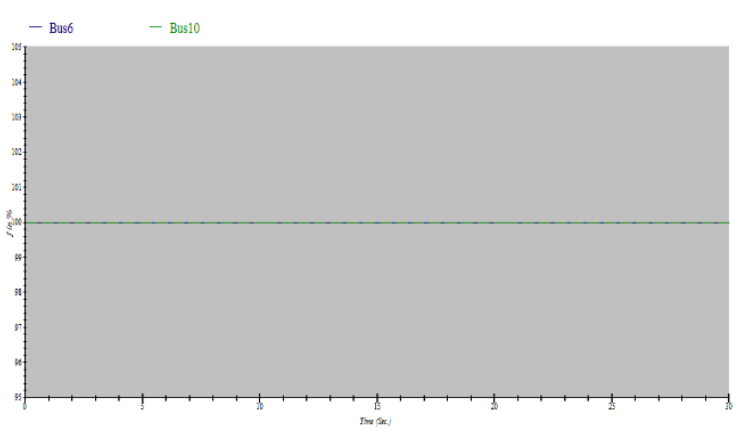

Figure 4.12 Response of Frequency Stability of Normal Conditions

For the response of rotor angle stability, normal conditions will be shown in Figure 4.3 below.

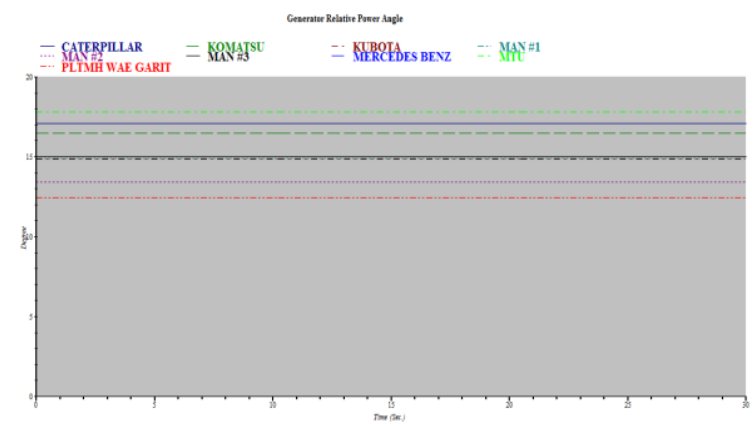

Figure 4.3 Response of Rotor Angle Stability in Generators in Manggarai Electrical Systems

The results of the response of voltage, frequency and rotor angle profiles in the Manggarai Electrical System under normal conditions will be stated in the table below.

Table 4.1 Response Value of Rotor Angle Stability in Generators in the Manggarai Electrical System

\begin{tabular}{|l|l|l|}
\hline \multirow{2}{*}{ ID Bus } & \multicolumn{2}{|l|}{$\begin{array}{l}\text { Normal } \\
\text { Condition }\end{array}$} \\
\cline { 2 - 3 } & $\boldsymbol{V}(\mathbf{p u})$ & $\boldsymbol{f ( H z )}$ \\
\hline Bus 6 & 0,9832 & 50 \\
\hline Bus 10 & 0,9891 & 50 \\
\hline
\end{tabular}

Table 4.2 Response Value of Rotor Angle Stability in Generators in the Manggarai Electrical System

\begin{tabular}{|l|l|}
\hline \multirow{2}{*}{ ID Generator } & Normal Condition \\
\cline { 2 - 2 } & Rotor Angle $(\delta)$ \\
\hline Mercedes Benz & 0 \\
\hline Caterpillar & 17.07 \\
\hline Komatsu & 16.47 \\
\hline Kubota & 14.87 \\
\hline Man \#1 & 14.77 \\
\hline Man \#2 & 13.43 \\
\hline Man \#3 & 15 \\
\hline Mtu & 17.8 \\
\hline PLTMH Wae Garit & 12.43 \\
\hline
\end{tabular}

\section{b. Rotor Stability, Frequency and Angle Conditions} Phase Fault Conditions.

This condition is a 3 phase fault condition that occurs on bus 6 . The fault occurs in the 1 st second and the interference is eliminated at 1.3 seconds.

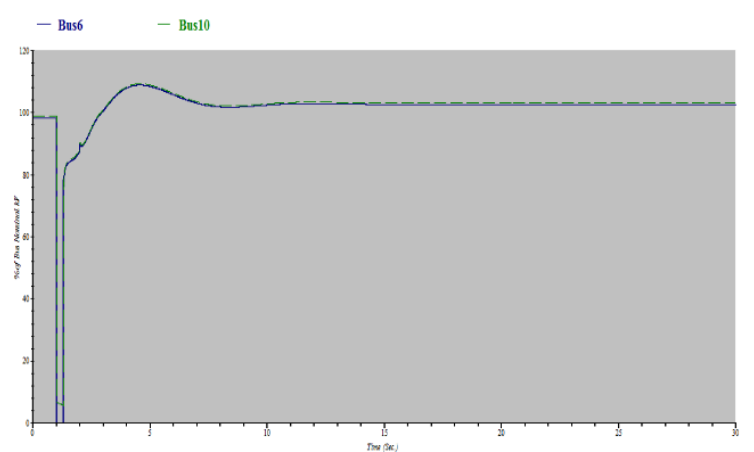

Figure 4.4 Response of Voltage Stability Value for Phase 3 Disorders

Figure 4.4 is the result of a voltage stability simulation after experiencing interference. For the simulation results the stability of the frequency after the 
disturbance will be shown in Figure 4.5 below.

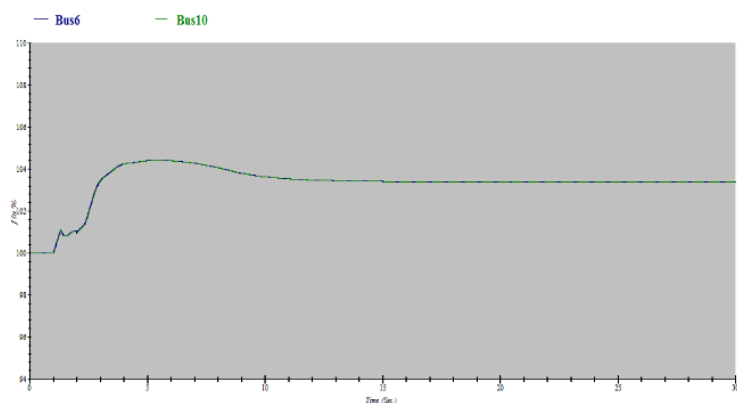

Figure 4.5 Response to the Stability of the Frequency of Phase 3 Disorders

The rotor angle response on each generator changes from seconds 1 to seconds 1.3 after that the rotor angle of the generator undergoes oscillation and finds a new working point of stability but with a long duration of oscillation

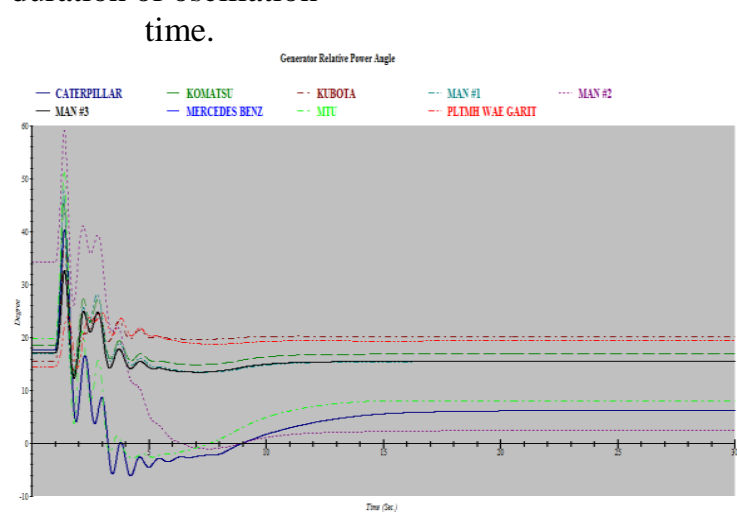

Figure 4.5 Response of Rotor Angle Stability Condition of Phase 3 Disorders

The result of the response of voltage, frequency and rotor angle profiles in the Manggarai Electrical System, the disturbance conditions will be stated in the table below.

Table 4.3 Value of Rotor Angle Stability Response in Generators in the Manggarai Electrical System

\begin{tabular}{|l|l|l|}
\hline \multirow{2}{*}{ ID Bus } & \multicolumn{2}{|c|}{ Fault Condition } \\
\cline { 2 - 3 } & $\boldsymbol{V}(\boldsymbol{p u})$ & $\boldsymbol{f}(\mathbf{H z})$ \\
\hline Bus 6 & 0,7877 & 50.5 \\
\hline Bus 10 & 0,783 & 50.5 \\
\hline
\end{tabular}

Table 4.4 Rotor Angle Stability Response When Three Phase Disorders Occur

\begin{tabular}{|l|l|}
\hline \multirow{2}{*}{ ID Generator } & Fault Condition \\
\cline { 2 - 2 } & Rotor Angle $(\delta)$ \\
\hline Mercedes Benz & 0 \\
\hline Caterpillar & 36.7 \\
\hline Komatsu & 44.11 \\
\hline Kubota & 34.63 \\
\hline Man \#1 & 46.98 \\
\hline Man \#2 & 56.32 \\
\hline Man \#3 & 30.25 \\
\hline Mtu & 48.16 \\
\hline PLTMH Wae Garit & 30.12 \\
\hline
\end{tabular}

\section{B. Transient Stability of Ulumbu PLTP}

Normal conditions are conditions in which the system has not experienced interference or the system is still in normal condition. Under normal circumstances this will be seen in the normal condition of the voltage, frequency and angle of the rotor from the Ulumbu PLTP generator when there have not been 3 phase disturbances. The bus that will see the response is bus 9 because on this bus it will be given a 3 phase interference.

\section{a). Normal Voltage, Frequency and Angle Stability Stability}

Normal stress conditions will be shown in Figure 4.6 below. The bus that is evaluated for the transient stability response of the voltage and frequency is bus 9 . From this voltage response it can be seen that the voltage response on bus 9 is still within the allowable

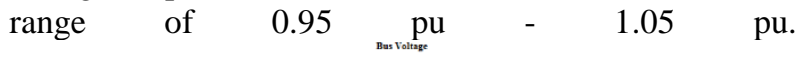

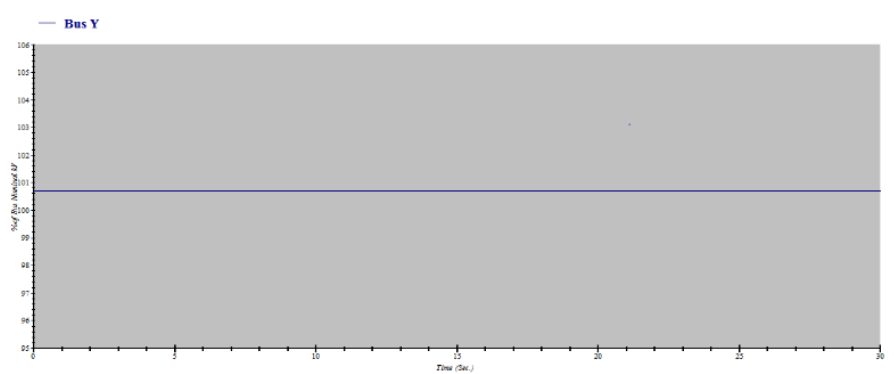

Figure 4.6 Voltage Stability Response When Normal Conditions

The frequency stability value of the normal condition of the bus 9 system will be shown in Figure 4.7. From the simulation results it can be seen that the frequency response on bus 9 is also still within the allowable range of $47.5 \mathrm{~Hz}-52.0 \mathrm{~Hz}$.

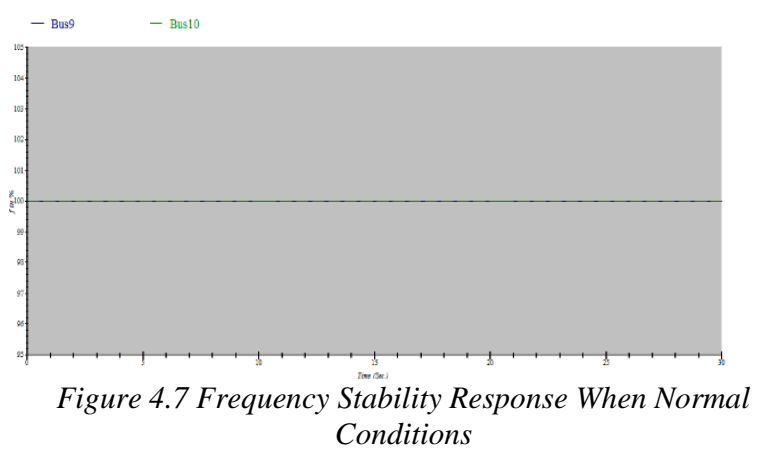

The simulation results of rotor angle stability under normal conditions are shown in Figure 4.8 below. The rotor angle response shown in the simulation is the Ulumbu PLTP generator which has different characteristics so that the typical response from the rotor angle for each of the different generators can be represented. 


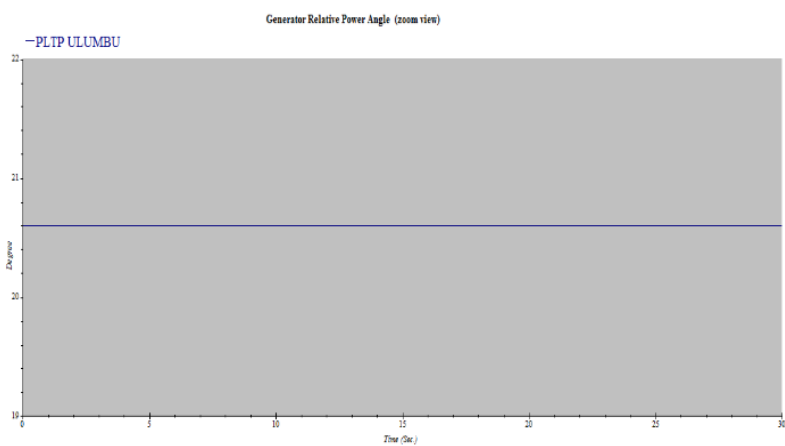

Figure 4.8 Normal Condition of Rotor Rotor Stability Response

Table 4.7 The Response Value of Rotor Angle Stability in Generators in the Manggarai Electrical System

\begin{tabular}{|l|l|l|}
\hline \multirow{2}{*}{ ID Bus } & \multicolumn{2}{|l|}{$\begin{array}{l}\text { Normal } \\
\text { Condition }\end{array}$} \\
\cline { 2 - 3 } & $\boldsymbol{V}(\mathbf{p u})$ & $\boldsymbol{f ( H z )}$ \\
\hline Bus 9 & 1.004 & 50 \\
\hline
\end{tabular}

Table 4.8 Rotor Angle Stability Response When 3 Phase Disorders Occur

\begin{tabular}{|l|l|}
\hline \multirow{2}{*}{ ID Generator } & Normal Condition \\
\cline { 2 - 2 } & Rotor Angle $(\delta)$ \\
\hline PLTP Ulumbu & 20.29 \\
\hline
\end{tabular}

\section{Rotor Stability, Frequency and Angle Conditions} 3 phase interference

This 3 phases disturbance occurs when all the loads in the Manggarai electrical system are only served by the Ulumbu PLTP while the Wae Garit PLTD and the Waso PLTD are turned off. Interference occurs on bus 9 near feeder 5 or feeder Iteng.

Determination of the critical termination time is obtained from the calculation using the same criteria method large. The critical termination time obtained from the calculation is 0.4 seconds.

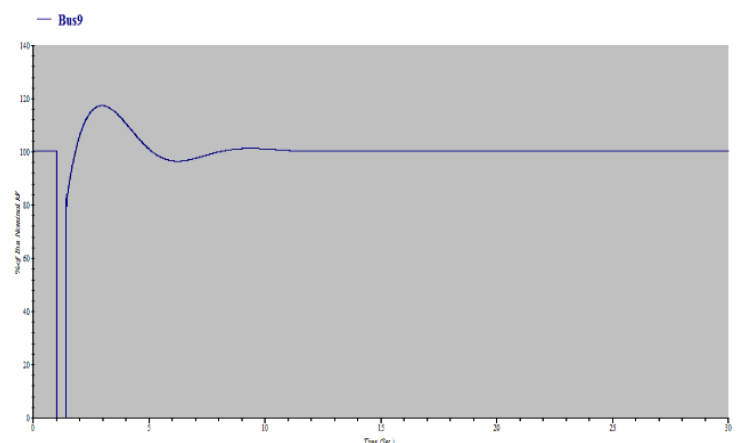

Figure 4.9 Voltage Stability Response Conditions for Phase 3 Disorders

For the simulation results, the stability of the frequency after the disturbance will be shown in Figure 4.10 below.

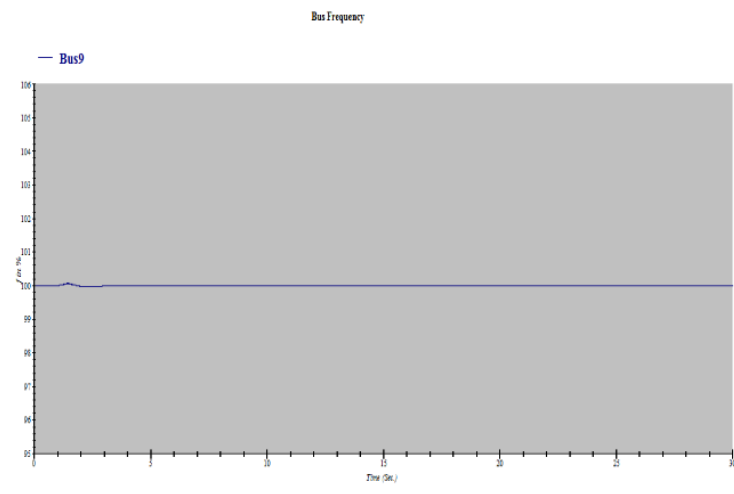

Figure 4.10 Stability Response Conditions for Phase 3 Disorders

The value of the change in the stability of the rotor angle of the Ulumbu PLTP when there is a balanced 3 fasa disturbance is shown in Figure 4.11 below:

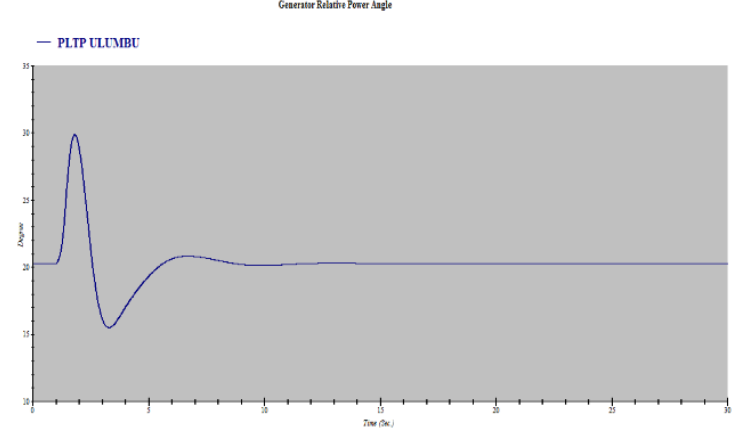

Figure 4.11 Rotor Angle Stability Response Condition Phase 3 Disturbance

Table 4.7 The Response Value of Rotor Angle Stability in Generators in the Manggarai Electrical System

\begin{tabular}{|l|l|l|}
\hline \multirow{2}{*}{ ID Bus } & \multicolumn{2}{|l|}{$\begin{array}{l}\text { Disruption } \\
\text { Conditions }\end{array}$} \\
\cline { 2 - 3 } & $\boldsymbol{V}(\boldsymbol{p u})$ & $\boldsymbol{f}(\boldsymbol{H z})$ \\
\hline Bus 9 & 0.7382 & 50 \\
\hline
\end{tabular}

Table 4.8 Rotor Angle Stability Response When 3 Phase

\begin{tabular}{|l|l|}
\multicolumn{2}{c}{ Disorders Occur } \\
\hline \multirow{3}{*}{ ID Generator } & $\begin{array}{l}\text { Disruption } \\
\text { Conditions }\end{array}$ \\
\cline { 2 - 2 } & Sudut Rotor $(\delta)$ \\
\hline PLTP Ulumbu & 24.62 \\
\hline
\end{tabular}

\section{CONCLUSION}

Based on the results of transient stability analysis and simulation to determine Critical Clearing Time when there was a 3 phase disturbance on the Ulumbu PLTP and due to the Ulumbu PLTP injection into the Manggarai electrical system, the following conclusions can be drawn:

With the results of the calculation of the Critical Clearing Time value on the Ulumbu geothermal power plant when there is a disturbance on one of the buses (Bus 9) that is equal to 0.4 seconds when there is a 3 phase interference, the response from the rotor angle of the system returns to its normal state after experiencing isolation for a long time. The response of the rotor angle value when experiencing 3 phases is greater, namely 20.29 degrees compared to the normal state of 24.62 degrees 


\section{REFERENCES}

[1] Rosidin M. Khaikal, Abraham Lomi, dan Irrine Budi Sulistiawati. Analisis Kestabilan Dinamik Akibat Injeksi PLTU LED (Lombok Energy Dynamics) Pada Sistem Kelistrikan Lombok. Teknik Elektro. Institut Teknologi Malang: Malang

[2] Patel, Mahendra, Niseet Soni. 2016. Assasment of Transient of Power System by Using Equal Area Criteria. Jabalpur (M.P), [INDIA]: International Journal of Modern Engineering \& Management Research Technology.

[3] Khiyavi, Poorghasemi, Asgar, dkk. 2015. The Study and Analysis New Method for Improving Transient Stability IEEE 9 Bus System. Islamic Azad University Gonabad Branch: $7^{\text {th }}$ Iranian Conference on Electrical and Electronics Engineering.

[4] Cekdin, cekmas. (2010). Sistem Tenaga Listrik - Contoh Soal dan Penyelesaiannya Menggunakan MATLAB. Edisi II Yogyakarta: ANDI

[5] A. Pongtiku, James and Maickel Tuegeh. 2014. Analisa Stabilitas Transien Untuk Menentukan Waktu Pemutusan Kritis (Critical Clearing Time) Pada Jaringan Transmisi 70 kV PLTA Tanggari II-GI Sawangan Dengan Menggunakan Program Matlab. Manado: International Standard Serial Number (ISSN): 2301-8402.

[6] Amin, Nur Aqilah Binti Mohamad. 2013. Power System Transient Stability Analysis Using Matlab Software. Faculty of Electric and Electronic Engineering Universiti Tun Hussein Onn Malaysia.

[7] Grainger, J, J. And W.D. Stevenson, Jr. 1994. Power System Analysis. USA: McGraw-Hill Inc.

[8] Suyono, H., and Zainuddin, M. (2015). Injection Impact of Photovoltaic Distributed Generations (PVDG) on Power Distribution System Stability. Applied Mechanics and Materials International Journal. Trans Tech Publications. Switzerland. Vol. 785 (2015) pp 403-408. Doi:10.4028/www. scientific. net/AMM.785.231

[9] Selwa, Fetissi, Labed Djamel. 2014. Transient Stability Analysis of Synchronous Generator in Electrical Network. International Journal of Scientific \& Engineering Research. 